\title{
Cultivation characteristics and flavonoid contents of wormwood (Artemisia montana Pamp.)
}

\author{
Yong Joo Kim ${ }^{1}$, Jeong-Hoon Lee ${ }^{2^{*}}$, Sun-Ju Kim ${ }^{1^{*}}$ \\ ${ }^{1}$ Department of Bio-Environmental Chemistry, Chungnam National University, Daejeon, South Korea; \\ ${ }^{2}$ Department of Herbal Crop Research NIHHS, RDA, Eumseong, South Korea \\ *Corresponding Authors: kimsunju@cnu.ac.kr, artemisia@korea.kr
}

Received 21 October 2013; revised 22 November 2013; accepted 30 November 2013

Copyright (C) 2013 Yong Joo Kim et al. This is an open access article distributed under the Creative Commons Attribution License, which permits unrestricted use, distribution, and reproduction in any medium, provided the original work is properly cited.

\begin{abstract}
The aim of this study was to establish the optimum harvesting time and the content of flavonoids in the leaves, stems, and roots of Artemisia montana Pamp. A. montana was monitored from June to October in 2012. The yield of $A$. montana at high density $(30 \times 10 \mathrm{~cm})$ was higher than that of $A$. montana at low density $(30 \times 20$ and $30 \mathrm{~cm})$. Yield in terms of dry weight was increased with an extended growth period and development stage. High yield achieved at 2580 and 2757 $\mathrm{kg} \cdot 10 \mathrm{a}^{-1}$ in September and October, respectively. Among the leaves, stems, and underground plant organs, jaceosidin and eupatilin were mainly detected in the leaves, and the highest levels were observed in June, at values of 66.6 and $158.2 \mathrm{mg} \cdot 100 \mathrm{~g}^{-1}$, respectively. In contrast, apigenin was the major compound detected in the underground plant organs, with levels ranging from 21.2 to $29.5 \mathrm{mg} \cdot 100 \mathrm{~g}^{-1}$ until September. Therefore, optimal harvest times were between September and October, generating a high yield and adding economic value although a higher level of total flavonoids was observed in crops harvested in June.
\end{abstract}

Keywords: Artemisia montana; Flavonoids; Harvest Time; Plant Density

\section{INTRODUCTION}

Medicinal plants have long been recognized as natural herbs that have minimal to negligible side effects. As the culture of enhancing human well-being has gained popularity, scientists have engaged in extensive studies

${ }^{*}$ These corresponding authors contributed equally to this work. of medicinal plants, including studies on natural drugs, herbal cosmetics, and natural pigments [1-3].

In Korea, wormwood has been used as an herb. Artemisia spp. belongs to Compositae, and taxonomic estimates have indicated that 200 to 400 species exist worldwide [4]. Approximately 40 species of Artemisia are distributed in Korea, of which 26 species are recorded in the Color Illustrated Book about the Plants in Korea [5]. In Korean traditional medicine, Artemisia spp. is further classified as Chung-ho, Ae-yeop, In-jin, and Am-ryeo. According to the herbal pharmacopoeia, the Ae-yeop pertains to dried medicinal leaves and young stems of Artemisia argyi Lev., A. princeps var. orientalis (Pamp.) Hara., and A. montana Pamp. Ae-yeop has been used as a medicinal herb [6]; it imparts warmth to the body and controls blood circulation, body temperature, bleeding, and pregnancy. It has also been used as a remedy for abdominal pain due to complications, diarrhea, chronic diarrhea, hematemesis, epistaxis, melena, and amenorrhea [7]. Ae-yeop contains various compounds such as flavonoids, steroids, phenylpropanoids, terpenoids, peptides, sesquiterpenoids, monoterpenoids, and diterpenoids [8,9]. Among these, flavonoids are known to possess excellent antioxidant activity that effectively eliminates reactive oxygen species, as well as a variety of other biological activities, including anti-cancer and anti-inflammatory activities [10]. The major flavonoids in Ae-yeop include eupatilin, jaceosidin, apigenin, and eupafolin [9,11]. Its pharmacological activities include anti-cancer, anti-inflammatory, anti-diabetic, and antiallergic activities [12-15]. Eupatilin is known to have strong inhibitory effects on gastric ulcers and has been used as the main raw material for the preparation of natural drugs [16,17]. In addition, the size of $A$. montana commonly used as Ae-yeop is larger than the size of other wormwood species. It has also been proven to have antioxidant and anti-diabetic effects because of components such as caffeic acid, caffeoylquinic acid, catechol, 
hyperoside, and protocatechuic acid making this herb a potential drug resource $[18,19]$. However, agronomic evaluation of this crop has not been conducted properly because of difficulties in its morphological classification among similar species. To establish "Good Agricultural Practices" (GAP), plant growth characteristics and yields of wormwood (Artemisia montana Pamp.) were evaluated on the basis of plant density and harvest times. Consequently, this study examined changes in the flavonoid (apigenin, jaceosidin, and eupatilin) (Figure 1) contents on the basis of cultivation characteristics and harvest times of $A$. montana, to develop an economically significant crop.

\section{MATERIALS AND METHODS}

\subsection{Plant Materials}

A. montana was collected from Gyeongsangbukdo Ulleung-gun and planted in a test package at the Department of Herbal Crop Research of the Korean National Institute of Horticultural \& Herbal Science on May 10, 2012. The plants were stored at KMRH under the Voucher number: MPS0002514 (Figure 2). The plants were grown in seedling trays containing 200 holes in a greenhouse at the beginning of March 2012. After planting, the leaves were collected on the $10^{\text {th }}$ day of each month from July to October to investigate the crop characteristics. Samples were harvested five times every month from June to October for analysis of flavonoids. The test package was prepared using $2000 \mathrm{~kg} \cdot 10 \mathrm{a}^{-1}$ base manure and covered with black plastic bags. A randomized complete block design was used in triplicate. For planting density, spacing between furrows and rows was 90 and $30 \mathrm{~cm}$, respectively. The planting intervals were 10,20 , and $30 \mathrm{~cm}$. After planting, 20 specimens were evaluated three times at 30-day intervals. For extraction, block sampling was used. The quantity was converted to the number per $10 \mathrm{a}$ after harvesting in one $\mathrm{m}^{3}$ test environment.

\subsection{Seed Characteristics}

To determine the seed characteristics of A. montana, 20 seeds were randomly selected in triplicate. The shape, size, and color of the seeds were evaluated. For 1000seed weight, the average value of 10 measurements was calculated. For germination, seeds with uniform size and color, as well as devoid of pest contamination, were selected using a caliper and microscope. The selected seeds were placed in disposable petri dishes and maintained in constant-temperature incubators set at 15,20,25, and $30^{\circ} \mathrm{C}$. The petri dishes were lined with filter paper soaked with distilled water. Germination was defined as the emergence of young leaves and roots of approximately 1 $\mathrm{mm}$ in length through the seed coat. The first germination time, bud burst period and germination rate were monitored.

\subsection{Equipment and Reagents}

Flavonoid standards, jaceosidin, and eupatilin were purchased from Chengdu Biopurify Phytochemicals Ltd. (Chendu, Sichuan, China) and apigenin from SigmaAldrich (St. Louis, MO, USA). Seed characteristics were microscopically evaluated (Olympus SZ61; Olympus Co. Tokyo, Japan). Seed germination was monitored in a constant temperature incubator (Multi-Room Incubator, Wisecube, Wonju-si, Korea). Flavonoid analysis based on growth stage was performed using the Agilent 1100 series HPLC system (Agilent Technologies, CA, USA).

\subsection{Extraction and Analysis of Flavonoids}

Approximately $10 \mathrm{~g}$ of powder was extracted from each plant organ of $A$. montana by using methanol $(\mathrm{MeOH})$, thus generating $2.4 \mathrm{~g}$ from the leaves, $1.7 \mathrm{~g}$ from the stems, and $1.8 \mathrm{~g}$ from the roots. Each extract $(10 \mathrm{mg})$ was placed in a $2 \mathrm{~mL}$ Eppendorf tube and mixed with $1 \mathrm{~mL}$ of $\mathrm{MeOH}$. After $5 \mathrm{~min}$ of ultrasonic extraction, the extracts were centrifuged at $3,000 \mathrm{rpm}$ at $4^{\circ} \mathrm{C}$ for 5 $\mathrm{min}$. The supernatant was filtered using a $0.45 \mu \mathrm{m}$ PTFE hydrophilic syringe filter (i.d., $13 \mathrm{~mm}$ ) and collected in a vial for HPLC.

For the analysis of flavonoids, the Agilent 1100 Series HPLC system (Agilent Technologies, CA, USA) equipped with u-Bondapak TM C18 $(10 \mu \mathrm{m}, 3.9 \times 300 \mathrm{~mm}$, Waters, MA, USA) was used. Detection was conducted at a wavelength of $354 \mathrm{~nm}$, the flow rate was $1 \mathrm{~mL} \cdot \mathrm{min}^{-1}$, and the column oven temperature was set at $30^{\circ} \mathrm{C}$. Approximately $20 \mu \mathrm{L}$ of the sample was injected using an auto sampler. The mobile phase solvents used were solvent $\mathrm{A}$ [Water: $\mathrm{H}_{2} \mathrm{PO}_{4}(99.6: 0.4, \mathrm{v} / \mathrm{v})$ ] and solvent $\mathrm{B}$ [acetonitrile]. The gradient program used as follows: 0 $30 \mathrm{~min}, 30 \% \rightarrow 70 \%$ solvent $\mathrm{B} ; 30-40 \mathrm{~min}, 70 \% \rightarrow$<smiles>O=c1cc(-c2ccc(O)cc2)oc2cc(O)cc(O)c12</smiles><smiles>COc1cc(-c2cc(=O)c3c(O)c(OC)c(O)cc3o2)ccc1O</smiles><smiles>COc1ccc(-c2cc(=O)c3c(O)c(OC)c(O)cc3o2)cc1OC</smiles>

Figure 1. Chemical structure of flavonoids in A. montana. (a) apigenin; (b) jaceosidin; (c) eupatilin. 


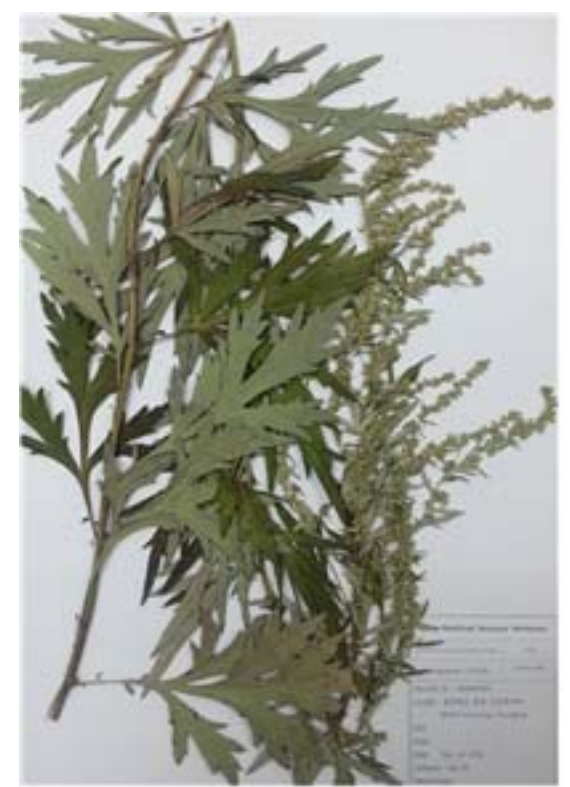

Figure 2. Specimen of A. montana. Horticultural traits: $A$. montana is a perennial plant that belongs to Asteraceae and has creeping roots and upright stems. The cauline leaves with hairs are alternately arranged. The size of $A$. montana is larger, compared to the closely related taxa.

$100 \%$ solvent $\mathrm{B} ; 40-50 \mathrm{~min}, 100 \% \rightarrow 30 \%$ solvent $\mathrm{B}$; 50 - 55 min, keep $30 \%$ solvent B. A stock solution of each flavonoid standards (apigenin, jaceosidin, and eupatilin) was made with $1 \mathrm{~mL}$ of $\mathrm{MeOH}$ and diluted with $\mathrm{MeOH}$ to make $50,100,200,250$, and $500 \mu \mathrm{g} \cdot \mathrm{mL}^{-1}$ for standard solutions. After taking $20 \mu \mathrm{L}$ of each standard solution, HPLC chromatography was conducted to quantify each component. A calibration curve was created using the concentration of the standard solution as the variable. The linear regression equation of the calibration curve of each component was apigenin, $y=7.2412 \mathrm{x}+$ 8.8393; jaceosidin, $y=9.6193 x+8.8391$; and eupatilin, $\mathrm{y}=8.5583 \mathrm{x}+6.1677$. The coefficient of determination was $\mathrm{R}^{2}=0.9999$. By substituting the HPLC peak area analyzed in each sample for the calibration curve regression equation, the amount of each compound $\left(\mu \mathrm{g} \cdot \mathrm{mL}^{-1}\right)$ was calculated. By calculating the yield, the extracts were quantified ( $\mathrm{mg} \cdot 100 \mathrm{~g}^{-1}$ of $\mathrm{MeOH}$ extracts).

\subsection{Statistical Analysis}

Data were analyzed by the application of the Duncan's multiple range test (DMRT, $n=3$ ) at $p \leq 0.05$ using the SAS statistical program (SAS 9.3, SAS Institute Inc., Cary, NC, USA). The F-value is the ratio of the mean square due to regression to the mean square due to error and indicates the influence (significance) of each controlled factor on the tested model.

\section{RESULTS AND DISCUSSION}

\subsection{Seed Characteristics}

A. montana seeds were oblong in shape, and the hairless achene was wrapped in a white fruit coat. The length, width, and 1000-seed weight were $1.37 \mathrm{~mm}, 0.52 \mathrm{~mm}$, and $0.110 \mathrm{~g}$, respectively (Figure 3). The first germination time was 2 days at $20^{\circ} \mathrm{C}-30^{\circ} \mathrm{C}$. However, the first germination time was 3 days at $15^{\circ} \mathrm{C}$. The bud burst period was observed at $20^{\circ} \mathrm{C}-30^{\circ} \mathrm{C}$ and at $15^{\circ} \mathrm{C}$ were 2 days and 5 days, respectively. This trend was similar to that of A. capillaris, which is a closely related species [20].

Germination rates at $15^{\circ} \mathrm{C}, 20^{\circ} \mathrm{C}, 25^{\circ} \mathrm{C}$, and $30^{\circ} \mathrm{C}$ were $84.7 \%, 90.0 \%, 92.7 \%$, and $87.3 \%$, respectively, which were slightly higher. The germination rate was the highest at $25^{\circ} \mathrm{C}$ (Figure 3). The germination rate of $\mathrm{A}$. montana increased up to a temperature of $30^{\circ} \mathrm{C}$, and, thereafter, decreased with higher temperature. Thus, $30^{\circ} \mathrm{C}$ was considered favorable for the initial germination of $A$. montana. Our results were consistent with the findings of Thompson [21]. Meanwhile, seed germination was closely related to environmental conditions, such as genetic differences, seed maturity, temperature, moisture, oxygen, and sunlight [22]. The temperature has been reported to have the greatest effect on germination rate [23,24]. Thus, when considering the seed characteristics of $A$. montana in this experiment, the optimum germination temperature was $25^{\circ} \mathrm{C}$. This condition can influence the distribution and seeding time of this species.

\subsection{Growth Characteristics by Planting Density}

The growth characteristics and yields of $A$. montana on the basis of planting density are shown in Table 1. Plant height ranged from 168.3 to $176 \mathrm{~cm}$. It appeared that a higher density was often associated with a smaller height. Such findings were contrary to the results of a few studies $[3,25,26]$, suggesting a higher planting density in Achyranthes japonica, Asparagus cochinchinensis, and Ligusticum chuanxiong. Results indicated that the heights of the plants were comparatively higher because of the competition among the species and decrease in light intensity. The results showed a similar tendency to that of Song et al. [27], who reported that a higher planting density in $P$. sonchifolia and $W$. japonica led to a lesser height because of competition between species [1]. Leaf dry weight ranged from 32 to $79.3 \mathrm{~g}$. A lower plant density was associated with a higher leaf dry weight. The dry weight of the aerial plant organs per 10 a was the highest in the $30 \times 10 \mathrm{~cm}$ plots. However, no significant differences were observed between the result and planting distance of $30 \times 20 \mathrm{~cm}$. A higher number of aerial plant organs of $A$. montana were associated with a 


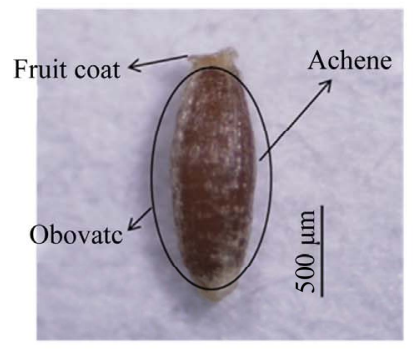

(a)

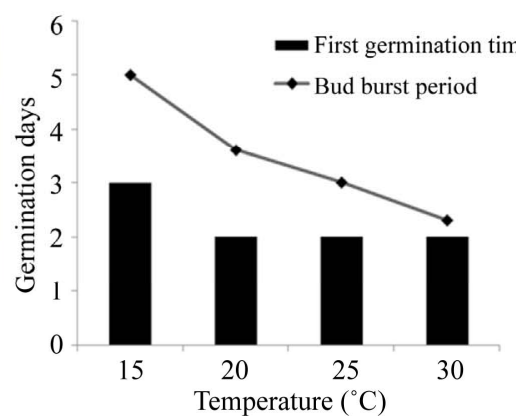

(b)

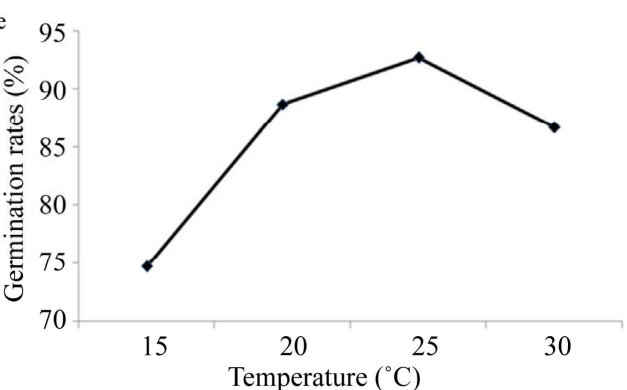

(c)

Figure 3. Plant growth characteristics of A. montana according to different temperatures. (a) seed characteristics; (b) first germination time and bud burst period (days); (c) germination rates (\%).

Table 1. Plant growth characteristics and yields of $A$. montana according to plant density in September.

\begin{tabular}{|c|c|c|c|c|c|c|c|}
\hline \multirow{2}{*}{$\begin{array}{l}\text { Plant density } \\
\quad(\mathrm{cm})\end{array}$} & \multirow{2}{*}{$\begin{array}{l}\text { No. of plant } \\
\left(\mathrm{ea} \cdot 10 \mathrm{a}^{-1}\right)\end{array}$} & \multirow{2}{*}{$\begin{array}{l}\text { Plant height } \\
(\mathrm{cm})\end{array}$} & \multirow{2}{*}{$\begin{array}{l}\text { Stem diameter } \\
(\mathrm{mm})\end{array}$} & \multirow{2}{*}{$\begin{array}{l}\text { Leaf weight } \\
\text { (g, dry weight) }\end{array}$} & \multirow{2}{*}{$\begin{array}{l}\text { Dry weight } \\
\text { ratio (\%) }\end{array}$} & \multicolumn{2}{|c|}{ Yield $\left(\mathrm{kg} \cdot 10 \mathrm{a}^{-1}\right.$, dry weight) } \\
\hline & & & & & & $\begin{array}{c}\text { Aerial part } \\
\text { organ }^{\text {a) }}\end{array}$ & $\begin{array}{l}\text { Underground part } \\
\text { organ }\end{array}$ \\
\hline $30 \times 10$ & 30,000 & $168.3 \pm 4.10 \mathrm{a}$ & $8.7 \pm 1.40 \mathrm{a}$ & $32.0 \pm 1.50 \mathrm{c}$ & $55.3 \mathrm{a}$ & $2580 \pm 224.0 \mathrm{a}$ & $480.0 \pm 91.24 \mathrm{a}$ \\
\hline $30 \times 20$ & 15,000 & $171.5 \pm 6.17 \mathrm{a}$ & $9.9 \pm 1.87 \mathrm{a}$ & $53.2 \pm 8.14 \mathrm{~b}$ & $58.4 \mathrm{a}$ & $2330 \pm 91.65 \mathrm{a}$ & $532.5 \pm 68.74 \mathrm{a}$ \\
\hline $30 \times 30$ & 9,000 & $176.0 \pm 6.42 \mathrm{a}$ & $10.2 \pm 170 \mathrm{a}$ & $79.3 \pm 4.25 \mathrm{a}$ & $47.9 b$ & $1847 \pm 69.18 b$ & $559.5 \pm 53.31 \mathrm{a}$ \\
\hline \multicolumn{2}{|c|}{ F-value } & $1.41^{\mathrm{NS}}$ & $0.70^{\mathrm{NS}}$ & $233.53^{* * *}$ & $12.60^{* *}$ & $19.75^{* *}$ & $0.93^{\mathrm{NS}}$ \\
\hline
\end{tabular}

Within each column, values followed by the same letters in a column are not significantly different at $p \leq 0.05(n=3)$. Significance level about F-value is represented at ${ }^{*} p<0.05 ;{ }^{* *} p<0.01 ;{ }^{* * *} p<0.001 ;{ }^{\text {NS }}$ not significant. ${ }^{\text {a) }}$ Aerial plant organ indicated above-ground parts including stems and leaves.

greater planting density. These results were similar to that of other medicinal plants such as A. japonica, $A$. cochinchinensis, and L. chuanxiong [3,25,26].

\subsection{Growth Characteristics by Harvest Time}

Growth characteristics and yields of $A$. montana on the basis of harvest time were investigated using $30 \times 10 \mathrm{~cm}$ plots (Table 2). The height sharply increased from 122.87 to $169.4 \mathrm{~cm}$ during the period of July-August, without showing considerable differences after August. The rainy season in July may have affected the growth of A. montana because of the sufficient water and sunlight. After the flowering period in August, growth stopped. The stem diameter was the greatest in August when the growth rate was the highest. Significant differences were observed between August and other times. Leaf dry weight was the highest in October. A longer growth period was associated with a higher yield. Dry weight ratio during the growth period decreased by $44.7 \%$ in September and by $71.9 \%$ in July. It may be possible that after the rainy season of July to August, the high moisture content caused the higher dry weight ratio; in contrast, in September the hot and dry weather caused the lower levels of moisture content and dry weight ratio. Since September, the dry weight ratio has remained almost constant. Apparently, the reason was that the change in climate after September was not significant. The dry weight of the aerial plant organs by harvest time was $2757 \mathrm{~kg} \cdot 10$ $\mathrm{a}^{-1}$, which was the highest in October. No significant differences were observed between the results collected in October, $2757 \mathrm{~kg} \cdot 10 \mathrm{a}^{-1}$, and the dry weight of the aerial plant organs harvested in September, $2580 \mathrm{~kg} \cdot 10$ $\mathrm{a}^{-1}$. Thus, considering leaf dry weights and the yields, the optimal harvesting time for A. montana was the period between mid-September and early October.

\subsection{Flavonoid Analysis}

Jaceosidin and eupatilin were detected only in the leaves, whereas apigenin was detected in the roots (Table 3). Contents of jaceosidin and eupatilin with respect to harvest time showed a similar pattern, and the contents in the leaves harvested in June were the highest levels (66.6 and $158.2 \mathrm{mg} \cdot 100 \mathrm{~g}^{-1}$, respectively). The contents of jaceosidin and eupatilin significantly decreased in July. The contents of jaceosidin and eupatilin in the leaves of A. princeps collected in May were the highest (38.6 and $211.4 \mathrm{mg} 100 \mathrm{~g}^{-1}$, respectively) [28]. The levels of monoterpene in $A$. princeps were documented the highest level in May 8, and they decreased rapidly after midMay [29]. Our results were similar to those of previous studies. The level of apigenin in the roots ranged from 21.2 to $29.5 \mathrm{mg} 100 \mathrm{~g}^{-1}$. The content increased from June to August and thereafter decreased. These results have also been observed in other medicinal plants such as $A$. 
Table 2. Growth characteristics and yields of $A$. montana in different harvest times.

\begin{tabular}{ccccccc}
\hline Harvest times & $\begin{array}{c}\text { Plant height } \\
(\mathrm{cm})\end{array}$ & $\begin{array}{c}\text { Stem diameter } \\
(\mathrm{mm})\end{array}$ & $\begin{array}{c}\text { Leaf weight } \\
(\mathrm{g}, \text { dry weight })\end{array}$ & $\begin{array}{c}\text { Dry weight } \\
\text { ratio }(\%)\end{array}$ & $\begin{array}{c}\text { Ratio of leaf } \\
\text { weight }(\%)\end{array}$ & $\begin{array}{c}\left.\text { Aerial part organ })^{\mathrm{a}}\right) \\
\left(\mathrm{kg} \cdot 10 \mathrm{a}^{-1}, \mathrm{dry} \mathrm{weight}^{2}\right.\end{array}$ \\
\hline July & $122.8 \pm 0.23 \mathrm{~b}$ & $8.9 \pm 0.59 \mathrm{~b}$ & $13.5 \pm 0.68 \mathrm{c}$ & $28.1 \mathrm{c}$ & $43.3 \mathrm{a}$ & $937.0 \pm 15.10 \mathrm{c}$ \\
August & $169.4 \pm 0.42 \mathrm{a}$ & $11.7 \pm 0.47 \mathrm{a}$ & $26.0 \pm 2.53 \mathrm{~b}$ & $35.1 \mathrm{~b}$ & $31.7 \mathrm{~b}$ & $2,459 \pm 62.45 \mathrm{~b}$ \\
September & $168.3 \pm 0.10 \mathrm{a}$ & $8.7 \pm 1.40 \mathrm{~b}$ & $32.0 \pm 1.50 \mathrm{ab}$ & $55.3 \mathrm{a}$ & $37.2 \mathrm{~b}$ & $2,580 \pm 224.0 \mathrm{ab}$ \\
October & $165.4 \pm 1.27 \mathrm{a}$ & $9.4 \pm 1.04 \mathrm{~b}$ & $39.3 \pm 7.66 \mathrm{a}$ & $51.6 \mathrm{a}$ & $42.8 \mathrm{a}$ & $2,757 \pm 137.2 \mathrm{a}$ \\
F-value & $187.31^{* * *}$ & $6.15^{*}$ & $21.92^{* * *}$ & $109.72^{* * *}$ & $10.46^{* *}$ & $115.73^{* *}$ \\
\hline
\end{tabular}

Within each column, values followed by the same letters in a column are not significantly different at $p \leq 0.05(n=3)$. Significance level about F-value is represented at ${ }^{*} p<0.05 ;{ }^{* *} p<0.01 ;{ }^{* * *} p<0.001 ;{ }^{\text {NS }}$ not significant. ${ }^{\text {a) }}$ Aerial plant organ indicated above-ground parts including stems and leaves.

Table 3. Flavonoid contents $\left(\mathrm{mg} \cdot 100 \mathrm{~g}^{-1}, n=3\right)$ in $\mathrm{MeOH}$ extracts of $A$. montana harvested at different development stages from June to October.

\begin{tabular}{|c|c|c|c|c|}
\hline Harvest times & Parts & Apigenin & Jaceosidin & Eupatilin \\
\hline \multirow{3}{*}{ June } & Roots & $21.2 \pm 0.40$ & $\mathrm{ND}^{\mathrm{a})}$ & ND \\
\hline & Stems & $\operatorname{tr}^{b)}$ & ND & ND \\
\hline & Leaves & ND & $66.6 \pm 2.18$ & $158.2 \pm 15.5$ \\
\hline \multirow{3}{*}{ July } & Roots & $24.8 \pm 0.97$ & ND & ND \\
\hline & Stems & TR & ND & ND \\
\hline & Leaves & ND & $4.5 \pm 0.32$ & $14.6 \pm 0.26$ \\
\hline \multirow{3}{*}{ August } & Roots & $29.5 \pm 0.24$ & ND & ND \\
\hline & Stems & TR & ND & ND \\
\hline & Leaves & ND & $17.6 \pm 0.32$ & $5.3 \pm 0.11$ \\
\hline \multirow{3}{*}{ September } & Roots & $25.7 \pm 0.18$ & ND & ND \\
\hline & Stems & TR & ND & ND \\
\hline & Leaves & ND & $0.9 \pm 0.05$ & $8.8 \pm 0.10$ \\
\hline \multirow{3}{*}{ October } & Roots & $11.2 \pm 0.12$ & ND & ND \\
\hline & Stems & $\mathrm{TR}$ & ND & ND \\
\hline & Leaves & ND & $2.1 \pm 0.06$ & $11.0 \pm 0.10$ \\
\hline
\end{tabular}

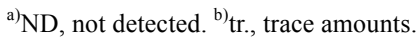

capillaris. Capillarisin content in A. capillaris increased until flowering time and thereafter decreased [30]. After August, which was the flowering time of $A$. montana, certain ingredients in the underground plant organs decreased.

The levels of active ingredients are influenced by climatic conditions, including precipitation and temperature. For A. princeps, whose Ae-yeop was used as herbal drugs, samples collected from April to May showed excellent antioxidant effects. The samples collected from August to September showed high antimicrobial activity [31]. Thus, according to the results of this study, A. montana had the potential of serving as natural drugs, and farmers may thus consider wormwood as an economically beneficial crop.

\section{REFERENCES}

[1] Byeon, H.S., Heo, S.J., Lim, S.J. and Seo, J.S. (2004) Effect of planting density on growth and yield of Wasabia japonica Matsum. Korean Journal of Medicinal Crop Science, 12, 300-303.

[2] Hwang, T.E. (2009) Changes in antioxidant activity during growth of Artemisia iwayomogi. Korean Journal of Medicinal Crop Science, 17, 286-292.

[3] Kim, D.H., Park, C.B. and Kim, J.Y. (2010) Effect of propagation method, planting density, amount of nitrogen fertilizer and cropping years on growth and yield of $A s-$ paragus cochinchinensis (Lour.) Merr. Korean Journal of Medicinal Crop Science, 18, 93-97.

[4] Lee, J.H., Park, C.B., Park, C.G. and Moon, S.G. (2010) A phylogenetic analysis of Korean artemisia L. based on ITS sequences. The Plant Resources Society of Korea, 23, 293-302.

[5] Lee, C.B. (2003) Color illustrated book about the plants (Second). Hyangmunsa, Seoul, 373-374.

[6] Korea Food \& Drug Administration (2013) National standard of traditional medicinal (herbal and botanical) materials. Shinilbooks, 125-126.

[7] Jung, B.S. and Sin, M.G. (1990) Herb medicine dictionary (plant). Yeongrimsa, Jeonju, 1014-1015. 
[8] Ryu, S.N. (2008) Bioactive constituents and utilities of Ganghwayakssuk (Artemisia princeps Pamp.). The Korean Society International Agriculture, 20, 308-314.

[9] Ganghwagun (2007) Artemisia princeps in Ganghwa. Academy, Incheon, 51-56.

[10] Kim, E.J., Choi, J.Y., Yu, M.R., Kim, M.Y., Lee, S.H. and Lee, B.H. (2012) Total polyphenols, total flavonoid contents, and antioxidant activity of Korean natural and medicinal plants. Korean Journal of Food Science and Technology, 44, 337-342. http://dx.doi.org/10.9721/KJFST.2012.44.3.337

[11] Bang, M.H., Kim, D.H., Yoo, J.S., Lee, D.Y., Song, M.C., Yang, H.J., Jeong, T.S., Lee, K.T., Choi, M.S., Chung, H.C. and Baek, N.I. (2005) Development of biologically active compounds from edible plant sources XIV. Isolation and identification of flavonoids from the aerial parts of sajabalssuk (Artemisia herba). The Korean Society for Applied Biological Chemistry, 48, 418-420.

[12] Kim, E.Y. and Kim, A.K. (2011) Enhancement of TRAILinduced apoptosis in human hepatocellular carcinoma cells by apigenin. Yakhak Hoeji, 55, 49-55.

[13] Jeong, M.A., Lee, K.W., Yoon, D.Y. and Lee, H.J. (2007) Jaceosidin, a phamacologically active flavone derives from Artemisia argyi, inhibits phorbol-ester-induced upregulation of COX-2 and MMP-9 by blocking phosphorylation of ERK-1 and -1 in cultured human mammary epithelial cells. New York Academy of Science, 1095, 458466.

[14] Kang, Y.J., Jung, U.J., Lee, M.K., Kim, H.J., Jeon, S.M., Park, Y.B., Chung, H.G., Baek, N.I., Lee, K.T., Jeong, T.S. and Choi, M.S. (2008) Eupatilin, isolated from Artemisia princeps Pampanini, enhances hepatic glucose metabolism and pancreatic $\beta$-cell function in type 2 diabetic mice. Diabetes Research and Clinical Practice, 82, 25-32. http://dx.doi.org/10.1016/j.diabres.2008.06.012

[15] Lee, S.H., Bae, E.A., Park, E.K., Shin, Y.W., Baek, N.I., Han, E.J., Chung, H.G. and Kim, D.H. (2007) Inhibitory effect of eupatilin and jaceosidin isolated from Artemisia princeps in IgE-induced hypersensitivity. International Immunopharmacology, 17, 678-684.

[16] Ryu, S.N., Han, S.S., Kim, K.S. and Jeong, H.G. (2006) Chemical component of mugwort (Artemisia princeps Pampanini) leaves collected in Korea. Korean Journal of Crop Science, 51, 220-223.

[17] Oh, T.Y., Ahn, B.O., Ko, J.I., Ryu, B.K., Son, M.W., Kim, S.H., Kim, W.B. and Lee, E.B. (1997) Studies on protective effect of DA-9601 an Artimisiae herba extract, against ethanol-induced gastric mucosal damage and its mechanism. The Korean Society of Applied Pharmacology, 5, 202-210.

[18] Lee, G.D., Kim, J.S., Bae, J.O. and Yoon, H.S. (1992) Antioxidative effectiveness of water extract and ether extract in wormwood (Artemisia montana Pampan.). The Korean Society of Food Science and Nutrition, 21, 17-22.

[19] Jung, H.A., Islam, M.D.N., Kwon, Y.S., Jin, S.E., Son, Y.K., Park, J.J., Sohn, H.S. and Choi, J.S. (2011) Extraction and identification of three major aldose reductase inhibitors from Artemisia montana. Food and Chemical
Toxicology, 49, 376-384

http://dx.doi.org/10.1016/j.fct.2010.11.012

[20] Lim, J.R., Choo, B.K., Park, C.B., Kim, D.H., Choi, J.S. and Choi, Y.G. (2004) Germination and growth characteristics in different sowing date of Artemisia capillaris Thunb. Korean Journal of Medicinal Crop Science, 12, 295-299.

[21] Thompson, P.A. (1970) Characterization of the germination response to temperature of dpecies and ecotypes. Nature, 225, 827-831. http://dx.doi.org/10.1038/225827a0

[22] Hwang, I.S., Yoo, J.H., Seong, E.S., Lee, J.G., Kim, H.Y., Kim, N.J., Lee, J.D., Ham, J.K., Ahn, Y.S., Kim, N.Y. and Yu, C.Y. (2012) The effect of temperature and seed soaking on germination in Cynanchum wilfordii (Maxim.) Hemsl. Korean Journal of Medicinal Crop Science, 20, 136-139.

http://dx.doi.org/10.7783/KJMCS.2012.20.2.136

[23] Heydecker, W. (1977) Stress and seed germination: An agronomic view. In: Elsevier, A.K., Ed., The Physiology and Biochemistry of Seed Dormancy and Germination, North Holland and Biomedical Press, Amsterdam, 237282.

[24] Bewley, J.D. and Black, M. (1982) Physiology and biochemistry of seeds in relation to germination. 2nd edition, Springer-Verlag press, New York, 365.

[25] Kim, G.C., Im, D.J., Yu, H.S. and Lee, S.T. (1994) Effect of planting density on the growth and yield of Ligusticum chuanxiong Hort. Korean Journal of Medicinal Crop Science, 12, 26-31.

[26] Kim, M.S., Chung, B.J., Park, G.C., Park, T.D., Kim, S.C. and Shim, J.H. (1998) Effect of planting density on the growth characteristics and root yield of Achyranthes japonica N. Korean Journal of Medicinal Crop Science, 6, 137-141.

[27] Song, I.G., Ho, Q.S., Hwang, S.G., Yun, J.S., Choi, I.S., Lee, C.H. and Lee, J.K. (1997) Effects of planting data and planting density on growth and tuber yield of yacon in the middle region. The Plant Resources Society of Korea, 10, 17-23.

[28] Ryu, S.N., Han, S.S., Yang, J.J., Jeong, H.G. and Kang, S.S. Variation of eupatilin and jaceosidin content of mugwort. The Korean Society of Crop Science, 50, 204-207.

[29] Kim, J.H. (1996) Seasonal variation in concentration and composition of monoterpenes from Artemisia princeps var. orientalis. Journal of Ecology and Environment, 19, 321-328.

[30] Choi, S.R., Ju, I.O., You, D.H., Song, Y.E., Jang, I. and Ryu, J. (2007) Changes of major components and growth characteristics according to harvesting times of Artemisia capillaris Thunberg. Korean Journal of Medicinal Crop Science, 15, 189-193.

[31] Yun, K.W., Jeong, H.J. and Kim, J.H. (2008) The influence of the growth season on the antimicrobial and antioxidative activity in Artemisia princeps var. orientalis. Industrial Crops and Products, 27, 69-74. http://dx.doi.org/10.1016/j.indcrop.2007.07.017 